\title{
Influence of apoptosis on liver and spleen resistance in dogs with visceral leishmaniosis
}

\author{
Influência da apoptose na resistência hepática e esplênica de cáes com leishmaniose visceral \\ Pamela Rodrigues Reina Moreira ${ }^{1 *}$; Douglas Augusto Franciscato²; Sabrina Micelli Rossit²; Danísio Prado Munari³ \\ Rosemeri de Oliveira Vasconcelos ${ }^{1}$

\begin{abstract}
${ }^{1}$ Departamento de Patologia Veterinária, Faculdade de Ciências Agrárias e Veterinárias - FCAV, Universidade Estadual Paulista UNESP, Jaboticabal, SP, Brasil

${ }^{2}$ Faculdade de Ciências Agrárias e Veterinárias - FCAV, Universidade Estadual Paulista - UNESP, Jaboticabal, SP, Brasil

${ }^{3}$ Departamento de Ciências Exatas, Faculdade de Ciências Agrárias e Veterinárias - FCAV, Universidade Estadual Paulista - UNESP,
\end{abstract} \\ Jaboticabal, SP, Brasil
}

Received June 20, 2016

Accepted July 22, 2016

\begin{abstract}
The aim of this study was to evaluate apoptosis and parasite load in the liver and spleen of dogs with visceral leishmaniosis (VL), using immunohistochemistry. Liver and spleen samples from $71 \mathrm{dogs}$ with VL were used. The parasite load in the spleen and liver showed significant difference between organs in infected group ( $\mathrm{P}=0.0219)$. The density of the parasite load in the spleen (median=2.4) was higher than liver (median=0.8). Immunodetection of apoptotic cells was predominant in lymphocytes and differ between the infected and control group in spleen $(\mathrm{P}=0.0307)$ and liver $(\mathrm{P}=0.0346)$. There was a significant correlation between apoptosis and parasite load $(\mathrm{P}=0.0084 ; \mathrm{r}=0.3104)$ only in the spleen of the infected group, where it was observed that, when increasing the number of apoptotic cells increases the parasitic load. It was concluded that the liver and spleen of infected dogs presented greater numbers of cells undergoing apoptosis (lymphocytes) than the control group, thus suggesting that this process may be contributing towards the survival of Leishmania in these organs, because lymphocyte in apoptosis did not have the ability to present and recognize the antigen, allowing the survival of the parasite.
\end{abstract}

Keywords: Leishmania infantum, immune escape, apoptosis, dogs.

\section{Resumo}

O objetivo deste estudo foi avaliar a apoptose e a carga parasitária no fígado e baço de cães com leishmaniose visceral (LV), pela técnica de imuno-histoquímica. Foram utilizadas amostras de fígado e baço de 71 cáes com LV. A carga parasitária no baço e fígado mostrou diferença significativa entre os órgãos no grupo infectado ( $\mathrm{P}=0,0219)$. A densidade da carga de parasita no baço (média=2,4) foi maior do que no fígado (média=0,8). A imunodetecção de células em apoptose foi predominante nos linfócitos, com diferenças entre o grupo infectado e controle no baço $(\mathrm{P}=0,0307)$ e fígado $(\mathrm{P}=0,0346)$. Houve uma correlaçấo positiva fraca entre apoptose e carga parasitária $(\mathrm{P}=0,0084 ; \mathrm{r}=0,3104)$ apenas no baço do grupo infectado, onde observou-se que quando aumentava o número de células em apoptose aumentava a carga parasitária. Concluiu-se que o fígado e o baço de cáes infectados apresentam um maior número de células que sofrem apoptose (linfócitos) do que o grupo controle, sugerindo que este processo possa contribuir para a sobrevivência de Leishmania nestes órgãos, pois os linfócitos em apoptose não tiveram a capacidade de apresentar e reconhecer o antígeno, permitindo a sobrevivência do parasita.

Palavras-chave: Leishmania infantum, evasão da resposta imune, apoptose, cáes.

\footnotetext{
*Corresponding author: Pamela Rodrigues Reina Moreira. Departamento de Patologia Veterinária, Faculdade de Ciências Agrárias e Veterinárias - FCAV, Universidade Estadual Paulista - UNESP, Via de Acesso Prof. Paulo Donato Castellane, s/n, CEP 14884-900, Jaboticabal, SP, Brasil.

e-mail: pamela_rreina@yahoo.com.br
} 


\section{Introduction}

Visceral leishmaniosis is a zoonosis caused by protozoa of the genus Leishmania. Dogs are considered to be the main reservoirs, outside of the wild environment. They are important for maintaining the epidemiological cycle of the disease, since visceral leishmaniosis is more prevalent in the canine population than in humans (REY, 2001). Human infection is almost always preceded by canine cases, since dogs present greater quantities of parasites on their skins. Infections in dogs can be divided according to the presence or absence of clinical signs (FEITOSA et al., 2000; BRASIL, 2006) and recently by urinalysis and urinary protein / creatinine ratio (SOLANO-GALLEGO et al., 2011).

The presence of systemic lesions is directly related to the host immune response and the evolution of the disease. Susceptible dogs have lesions that are more exuberant, and this is due to the tendency for a Th2 response to be developed, B lymphocytes to proliferate and a humoral response to be produced. Resistance to visceral leishmaniosis is associated with activation of Th1 cells. The main effector mechanism involved in the protective immune response of dogs infected with Leishmania infantum consists of activation of macrophages by IFN- $\gamma$ and TNF- $\alpha$ to destroy intracellular amastigotes, via L-arginine and synthesis of nitric oxide (BARBIÉRI, 2006).

Leishmania amazonensis contains phosphatidylserine (PS) in its external cellular membrane. PS induces synthesis of anti-inflammatory cytokines in the host, with inhibition of nitric oxide synthesis by macrophages and stimulation of TGF- $\beta$ and IL-10 production. These factors favor the entry and multiplication of parasites in macrophages. It has also been proven that PS is a potent stimulator of apoptosis (BARCINSKI et al., 2003). Experimental infection by Leishmania donovani has been shown to induce apoptosis of immune system cells that are not infected (CD4T lymphocytes), possibly due to the influence of the lipophosphoglycan (LPG) that is present in its cell wall (LÜDER et al., 2001).

Analysis of the immune response in chronic infection in the different compartments may be important for understanding the mechanisms of resistance or susceptibility of certain microenvironments in the presence of the pathogen. There is a scarcity of studies describing the histopathological characteristics of different compartments (organs) of the host that are affected by these parasites, such as the skin, spleen, liver, bone marrow and lymph nodes of dogs. Regarding the spleen, splenomegaly is macroscopically the most striking feature, caused by chronic inflammatory infiltrate and high density of parasites. Regarding the liver, an association between high intensity of inflammatory reaction and the parasite load in symptomatic dogs has been described (REIS et al., 2009).

Dogs infected with Leishmania have been shown to demonstrate different patterns of inflammatory reaction between the spleen and liver, in infected groups with or without clinical signs. In naturally infected dogs, intralobular granulomas were observed in the liver, with predominance of macrophages (with or without parasites), some lymphocytes and rare neutrophils. The spleen presented many lymphoblasts, macrophages, lymphocytes and apoptotic cells at the germinative center. The red pulp had a high level of parasitism (TAFURI et al., 1996).

The objective of the present study was to evaluate the apoptosis density in spleen and liver of dogs with visceral leishmaniosis, by immunohistochemistry, and to correlate these findings with the parasite load of each organ by group (infected or control).

\section{Material and Methods}

The dogs investigated in this study were originated from the Zoonosis Control Center in Araçatuba, (São Paulo State, Brazil), a region that is endemic for VL (MOREIRA et al., 2010; MOREIRA et al., 2013). Seventy-one Leishmania infantum infected dogs were used, without preference for age, breed or gender. The animals were euthanized using an intravenous (IV) overdose of barbiturate, followed by IV administration of potassium chloride (decree number 51.838 of the Brazilian Ministry of Health and Resolution number 714, of June 20, 2002, of the Federal Veterinary Medicine Council). The necropsy of the dogs was performed immediately after their death. The control group consisted of ten dogs from the routine of the Department of Veterinary Pathology Jaboticabal-SP, Brazil, a non-endemic area for VL (OLIVEIRA et al., 2008). Infected dogs and control dogs were selected, following confirmation or not of disease respectively, by RIFI and ELISA.

Fragments of liver and spleen were collected and fixed in 10\% formalin solution, for histopathological and immunohistochemical analyses (apoptotic cells and parasite load).

\section{Histopathological analysis}

The fragments of spleen and liver tissue were fixed in $10 \%$ formol solution, buffered with phosphate ( $\mathrm{pH}$ 7.2) for 24 hours and then processed and embedded in paraffin. Thin sections $(5 \mu \mathrm{m})$ were cut from this and were stained with hematoxylin and eosin in order to identify the main morphological alterations (presence or absence of granulomatous inflammation, inflammatory infiltrate score and degeneration). The lesion intensity was graded as: absence of lesions (0), mild (1), moderate (2) or severe (3), for the inflammatory infiltrate of macrophages and plasmacytes. The splenic lymphocytes were graded thus: (0) lymphoid atrophy, (1) mild, (2) moderate or (3) severe lymphoid reactivity. Graduation of the lymphoid cells was based on the reactivity of lymphoid nodules of the white pulp, according to Moreira et al. (2010), who evaluated lymphoid cells by reactivity of lymphoid nodules in the popliteal lymph nodes of dogs with Visceral Leishmaniasis.

\section{Immunohistochemical analysis}

In the immunohistochemical analysis, to determine the parasite load and apoptosis density, the streptavidin-biotin-peroxidase complex was used (LSAB kit, Dako Cytomation, catalog number K0690, Carpinteria, USA). For immunolabeling of the amastigote forms, hyperimmune serum from a leishmaniosis-positive dog (titer of 1:40,000, by means of the ELISA test) was used at a dilution 
of 1:1.000 (modified from TAFURI et al., 2004). To determine the density of apoptotic cells, cleaved anti-caspase 3 antibodies (Cell Signaling, catalog number 9661) were used at a dilution of 1:200. Both antibodies were incubated in a dark and humid environment for an 18 -hour period, at $4^{\circ} \mathrm{C}$. The antigen recovery system consisted of using steam (electric steam-generating panel, Philips Walita), with a $10 \mathrm{mM}$ sodium citrate solution ( $\mathrm{pH}$ 6.0). Endogenous peroxidase was blocked using a 3\% solution of methanol and 30 volumes of hydrogen peroxide (Synth), for 20 minutes. The nonspecific immunolabeling was blocked using a commercial product (Protein Block, Dako Cytomation, catalog number X0909, Carpinteria, USA), for 20 minutes of incubation. The chromogen used was diaminobenzidine (DAB, Dako Cytomation, catalog number K3468, Carpinteria, USA) and the counterstaining was done using Harris hematoxylin. To create a negative control, it was decided to exclude the primary antibody from the reaction. The positive control used for immunostaining of cells undergoing apoptosis was canine lymph nodes.

To determine the number of immunostained cells, five microscope fields were analysed (Nikon Eclipse E200) with a 40× objective lens (MOREIRA et al., 2010, 2013), which presented an area of approximately $0.19625 \mathrm{~mm}^{2}$, considering that for the density of cells in apoptosis, were counted all cells immunostained in the field, totaling five fields observed. For amastigotes of L. infantum, were counted the presence of parasitized macrophages in each field. From the values obtained in these fields, an average number of immunostained cells was determined for each group (Leishmania infected and negative controls).

\section{Statistical analysis}

Statistical analysis was done using the nonparametric Mann Whitney test, with comparisons between the groups of dogs (infected and control) to density of apoptotic cells and parasite load. The correlations between parasite load and apoptosis in the liver and spleen were determined using Spearman's correlation coefficient. The GraphPad Prism statistical software (version 4.00, 2003) was used for all the analyses, and differences were taken to be significant when $\mathrm{P}<0.05$.

\section{Results}

\section{Histopathological analysis}

In the hepatic samples analyzed, the intensity of the inflammation ranged from mild to moderate and was located in the centrilobular, portal and intralobular regions. In this organ, the inflammatory cells consisted predominantly of lymphocytes, plasmacytes and macrophages. In the remainder of the hepatic parenchyma, there were varying degrees of hydropic degeneration and congestion, along with the presence of reactive Kupffer cells. The intensity of the granulomatous inflammation was greater in the infected dogs in both organs. In liver was observed granulomas with well-defined edges (Figure 1a).

The spleen presented granulomas in the capsule and red pulp, composed predominantly of an infiltrate of macrophages and rare lymphocytes and plasmacytes. In this organ, in the more advanced cases, the granulomatous inflammation caused distortion of the splenic architecture. The splenic granulomas had multifocal distribution and undefined edges (Figure 1c). These granulomas predominated in the red pulp and were seen rarely in the germinative centers. Some Mott cells were present together with the plasmacytic infiltrate. In the white pulp, the lymphoid reactivity ranged from mild to moderate in infected dogs. Apoptosis was observed in lymphocytes from this area. The liver and spleen of control dogs didn't showed morphological changes (Figure 1b, d respectively).

\section{Immunohistochemical analysis}

In this study, cells with immunolabeled amastigote forms of $L$. infantum were observed in macrophages present in the hepatic inflammatory infiltrate (Figure 2a) and predominantly in macrophages of the splenic granulomas of the red pulp (Figure 2c). In the control group in both organs, did not were observed amastigote forms of Leishmania (Figure 2b, d).

Immunodetection of apoptotic cells (Figure 3) was mostly seen in the cytoplasm of the cells, with predominance of lymphocytes (T lymphocytes) in the mantle layer of the splenic corpuscle (white pulp), followed by the red pulp. Macrophages and plasmacytes also presented apoptosis, but in smaller proportions. On the other hand, there was little or no presence of apoptotic cells in the germinative center (B lymphocytes). Apoptosis was more evident and significant in the infected group compared to the control group, in the livers $(p=0.0346)$ and the spleens $(p=0.0307)$. In the liver, the density of apoptotic cells were higher in infected dogs (median 1.0) than control group (median 0.5; Figure 4). As well as in the spleen, where in the infected dogs (median of 4.8), when compared to control group (median of 1.8; Figure 4).

The density of parasite load in the infected group was significant between the organs $(\mathrm{p}=0.0219)$, where in the spleen $($ median $=2.4)$ and in the liver (median=0.8; Figure 4 ). The correlation between the parasite load and apoptosis $(\mathrm{p}=0.0084 ; \mathrm{r}=0.3104)$ was significant only in the spleen (infected group).

\section{Discussion}

Formation of granulomas with well-defined edges, rich in lymphocytes and plasmacytes, was observed in the liver. In the spleen, the granulomatous inflammation was multifocal to diffuse and it caused distortion of the architecture of this organ. There was small proportion of lymphocytes associated with splenic granulomas. Our results coincided with others studies (GIUNCHETTI et al., 2008; LIMA et al., 2007; TAFURI et al., 1996), who observed well-organized intralobular granulomas in the livers of infected dogs. The disorganized tissue architecture in the spleen relating to predominance of parasitized macrophages was observed in our study and others researches (SANTANA et al., 2008; TASCA et al., 2009).

In the present study, we suggest that these differences in granuloma cell profile could explain the differential response of these organs against the parasite. The splenic inflammation in the 


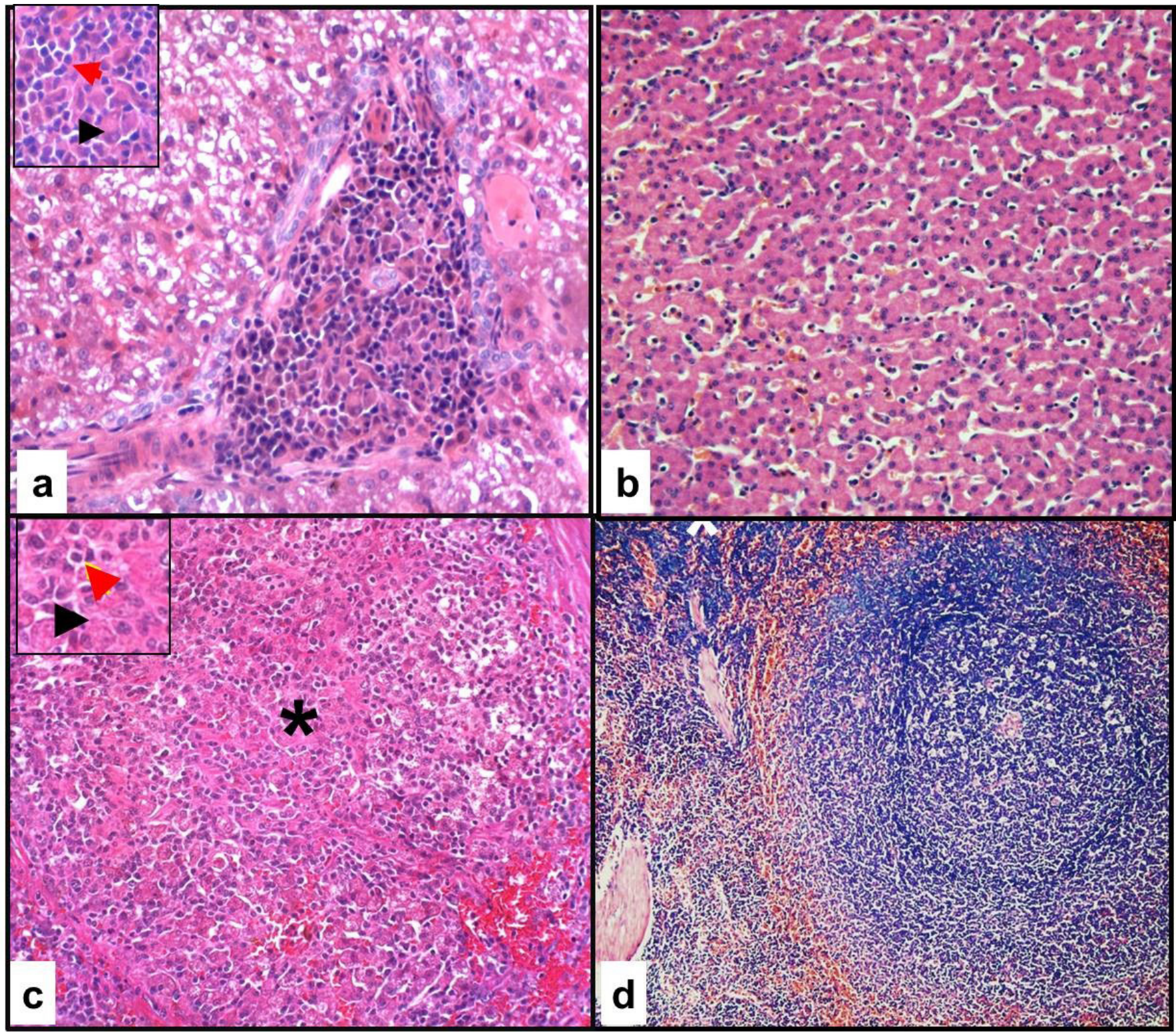

Figure 1. Photomicrographs of the liver and spleen of a dog infected and control groups. (a) Note the presence of a portal granuloma $(*)$. Detail showing hepatic granuloma rich in lymphocytes (red arrow) and rare macrophages (black arrow) in infected dogs (40× objective lens); (b) Note the absence of lesions in the liver control (20x objective lens); (c) The same lesion could be observed invading the splenic red pulp $\left.{ }^{*}\right)$. Detail showing splenic granuloma rich in macrophages (black arrow) and rare lymphocytes (red arrow) in infected dogs (40× objective lens); (d) Note the absence of lesions in the spleen control (10× objective lens). Hematoxylin and eosin.

infected group was predominantly composed for macrophages, which did not appear to be protective for the host, because the same organ had higher numbers of parasitized cells. The same type of granuloma was described in the popliteal lymph node. Predominance of macrophages associated with lymphoid atrophy and distortion of the popliteal architecture were evident in the symptomatic dogs (MOREIRA et al., 2010). The livers of the asymptomatic dogs presented well-formed granulomas containing T lymphocytes (SANCHEZ et al., 2004). In the present study, the liver of infected dogs with severe clinical course of VL showed disorganized granulomas and the Kupffer cells were parasitized.

In the liver, presence of severe hydropic degeneration in the infected dogs was also noted. In studies with dogs that had been experimentally infected with $L$. infantum, the authors observed severe tumefaction of hepatocytes, due to edema and degeneration of cytoplasmic organelles (mitochondria, endoplasmic reticulum and Golgi complex), thus resulting in cytolysis (GONZÁLEZ et al., 1998).

In the present study, the parasite load was low in the liver and elevated in the spleen. In the liver, the amastigote forms were located mainly in the multifocal granulomas, and in lower proportion in the Kupffer cells. In the spleen, the parasitized macrophages were predominantly in the red pulp region, as also described in literature (TAFURI et al., 1996). The differences between the numbers of cells parasitized in each organ were similar to literature (LIMA et al., 2007; TAFURI et al., 1996). 


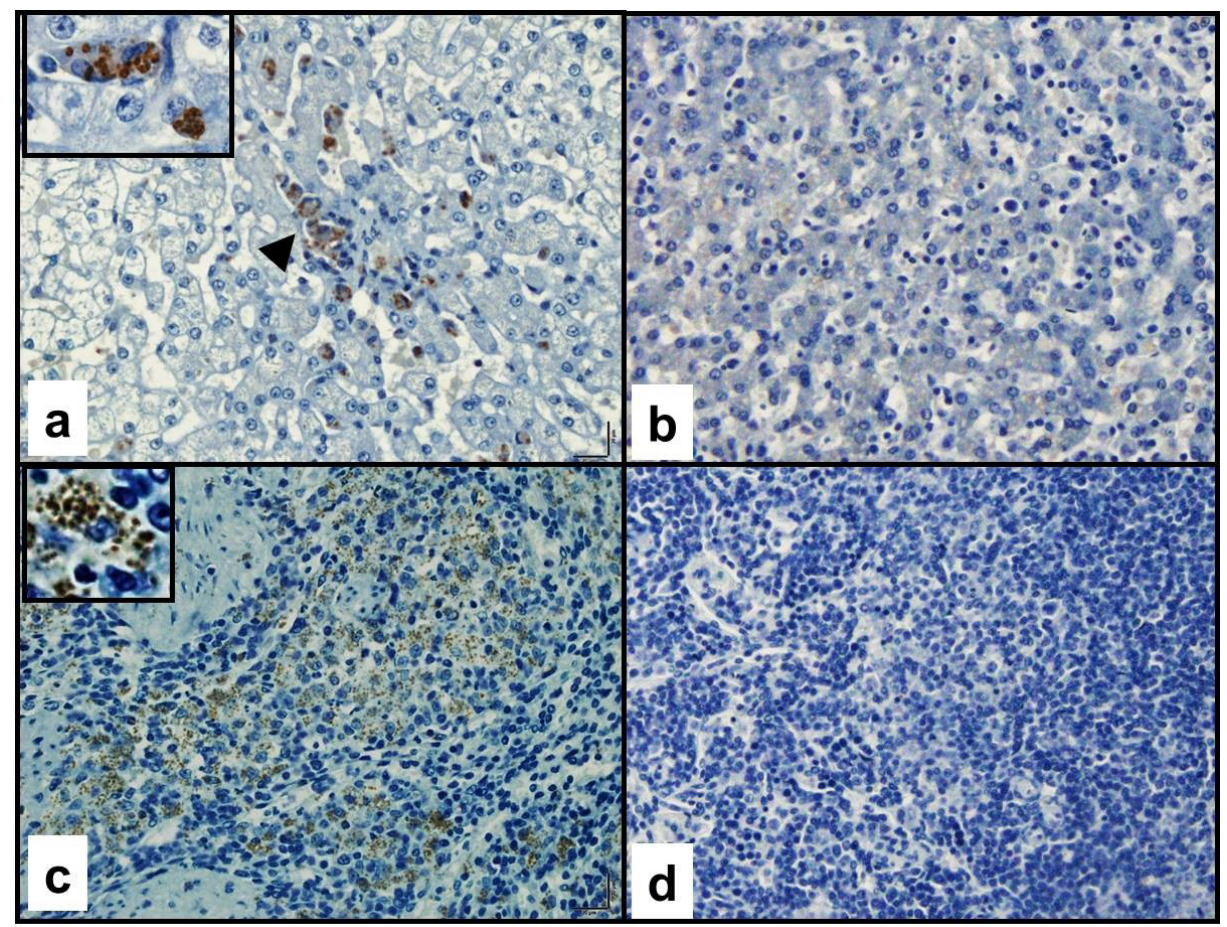

Figure 2. Photomicrographs of amastigote forms of Leishmania infantum in the liver and spleen of dogs with visceral leishmaniosis. (a) Liver with immunolabeled parasites in the cytoplasm of macrophages in the sinusoids (arrow; 40× objective lens; detail 100× objective lens); (b) Note the absence of parasite load in the liver (negative control of infection / 20x objective lens); (c) In the spleen note presence of parasites in red pulp (40× objective lens; detail 100× objective lens); (d) Note the absence of parasite load in the spleen (negative control of infection / 20× objective lens). Streptavidin-biotin-peroxidase complex.

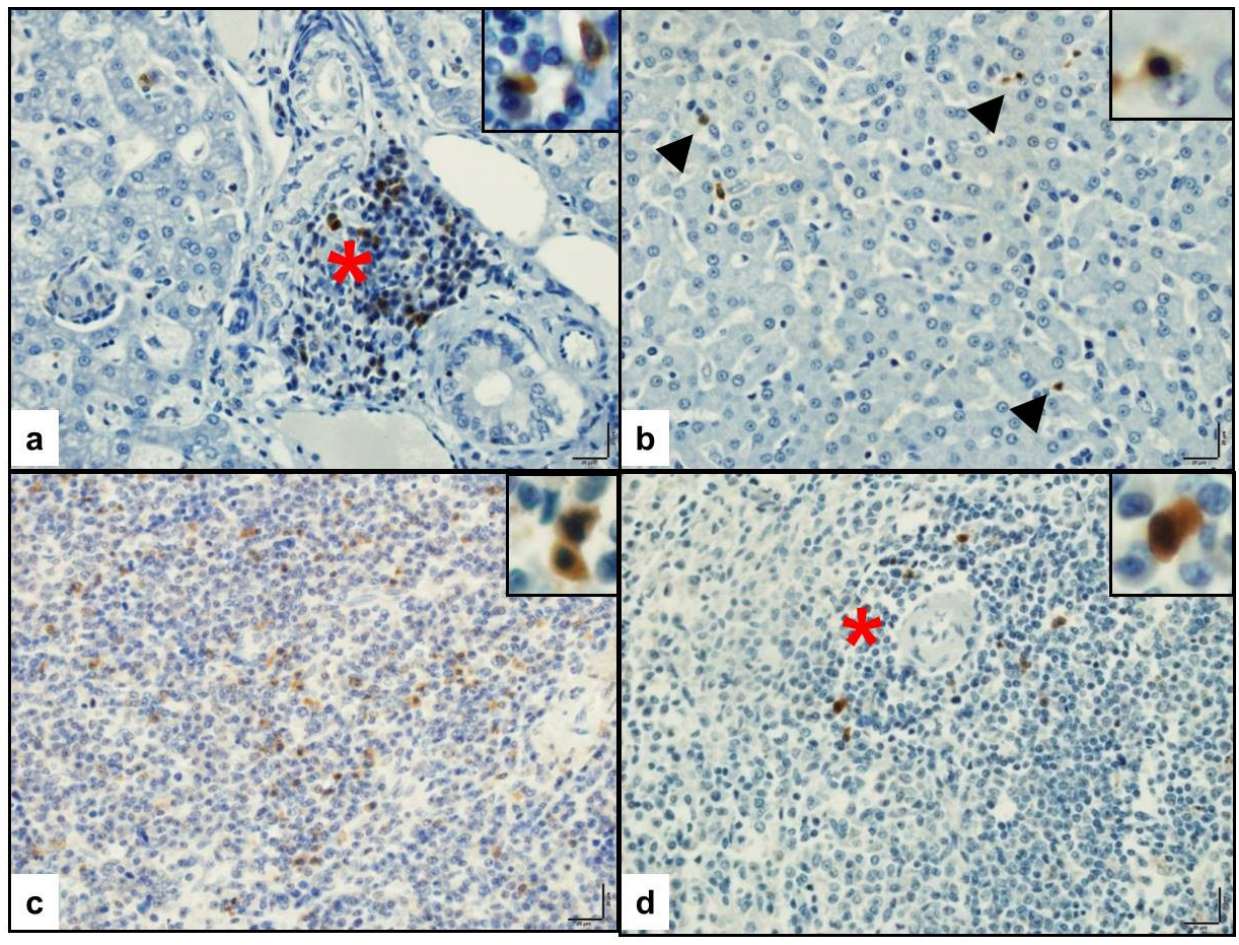

Figure 3. Photomicrographs of cells undergoing apoptosis, labeled with the cleaved caspase 3 antibody, in the livers and spleens of dogs with visceral leishmaniosis. (a) Liver of the infected group, with labeling of apoptosis in the inflammatory infiltrate (*; 40× objective lens; detail $100 \times$ objective lens); (b) Liver of the control group with immunodetection of apoptosis in the sinusoids (arrows; $40 \times$ objective lens; detail $100 \times$ objective lens); (c) Note marked presence of apoptosis in the white pulp of the spleen of the infected group (40× objective lens; detail $100 \times$ objective lens); (d) Spleen of uninfected dog (control group) with presence of apoptosis in the white pulp (*; $40 \times$ objective lens; detail $100 \times$ objective lens). Streptavidin-biotin-peroxidase complex. 
In the present study, the splenic parasite load is according to Melo et al. (2004) reports. These authors described that the spleen was a more suitable organ for making the parasitological diagnosis of infection by Leishmania spp.

\section{a}

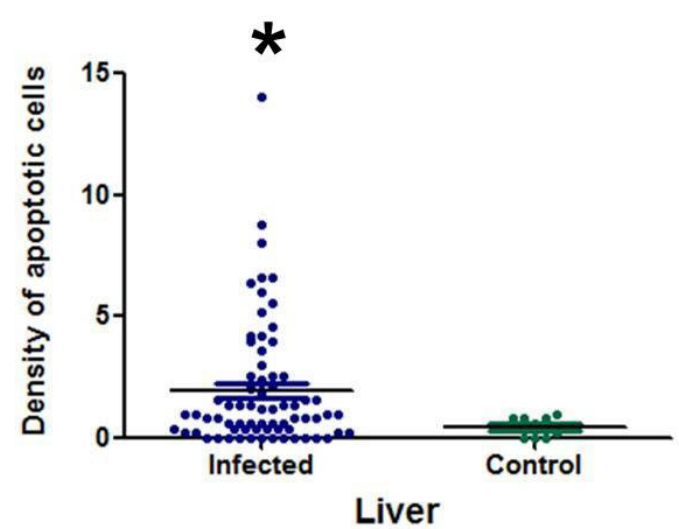

b

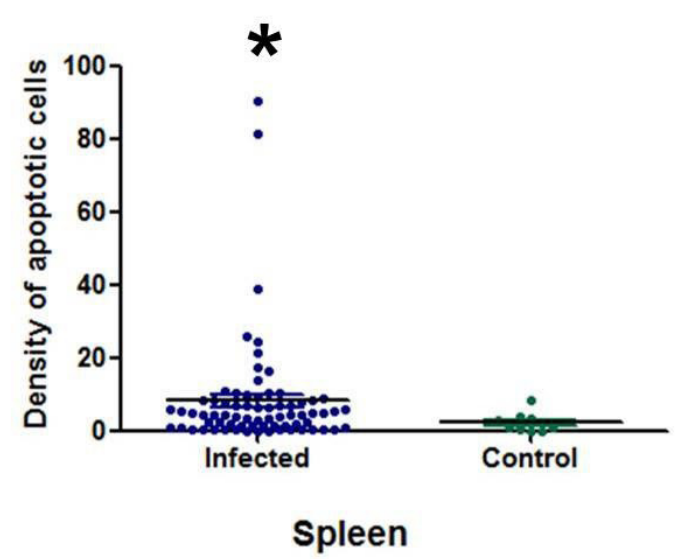

C

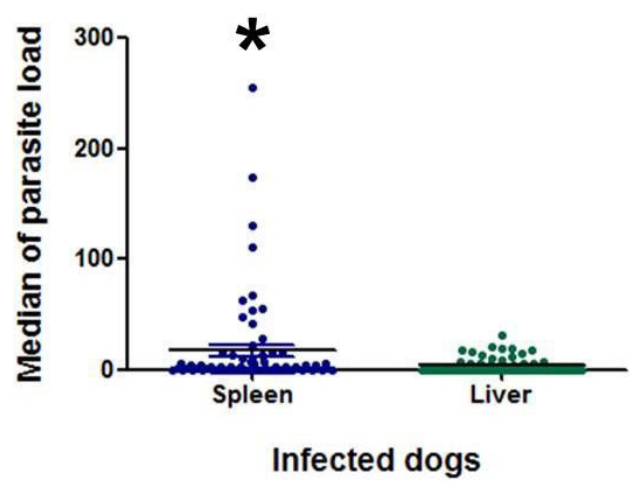

Figure 4. Density of apoptotic cells in liver (a) and spleen (b) of infected and control groups; (c) Density of parasite load observed in spleen and liver of infected dogs. Regarding the cells undergoing apoptosis, note significant difference between infected and control group, in liver $(\mathrm{p}=0.0346)$ and spleen $(\mathrm{p}=0.0307)$. The parasite load showed significant difference between spleen and liver in the infected group $(\mathrm{p}=0.0219)$. Mann Whitney test $\left({ }^{*} \mathrm{p}<0.05\right)$.
There was significant presence of apoptosis in the hepatic inflammatory infiltrate and in the spleen of infected dogs. The lymphocyte involvement was highly prevalent. These results coincided with those of Lima et al. (2012), who observed apoptosis in T cells of the spleen and peripheral blood, thus suggesting that this parasite could induce apoptosis in T cells in association with decreased cell-mediated immunity. Like in the present study, Verçosa et al. (2012) and Moreira et al. (2013) also observed larger numbers of cells undergoing apoptosis in the skin of symptomatic dogs with high parasite loads. Moreira et al. (2013) observed that lymphocytes predominated among the apoptotic cells.

The greater immunodetection of apoptotic lymphocytes observed in the groups of dogs with VL might be explained by the chronic stimulation of T lymphocytes, due to the oxidative environment created by the activated and parasitized macrophages. This exacerbated stimulation would lead to dysfunction of these lymphocytes, thereby resulting in apoptosis because of the harmful effects of reactive oxygen species (ROS). The antigen persistence results in exhaustion of T lymphocytes and cells with diminished expression of cell surface receptors and diminished expression of anti-apoptotic molecules ( $\mathrm{Bcl}-2)$. T cells with exhaustive phenotype have PD-1 expression (programmed death 1) and have increased sensitivity to Fas-FasL mediate apoptosis. In chronic infection, deletion of memory or non-activated $\mathrm{T}$ lymphocytes may occur, thus allowing the infection to evolve to chronicity (MURALI \& MEHROTRA, 2011).

In VL, chronicity of infection is a feature observed in the organs of naturally infected dogs. Inefficient activation of T lymphocytes seems to be one of the most important characteristics contributing towards survival of this protozoon in the tissues of canine hosts. Parasitized macrophages are key cells in this inefficient process of activation of $\mathrm{T}$ lymphocytes. Future studies for evaluate the role of subpopulations of these two types of cells may help in comprehending the complex pathogeny of this zoonosis.

\section{Conclusion}

It was concluded that the liver and spleen of the infected dogs presented larger numbers of cells undergoing apoptosis than what was seen in the control group. The positive correlation between the parasite load and apoptosis was observed only in the spleen. The lymphocytes in apoptosis did not have the ability to present and recognize the antigen, which suggests that this process may have been contributing towards the survival of the protozoon in these organs.

\section{Ethical Standards}

The design for this study was approved by the Ethics and Animal Welfare Committee (CEUA no. 000599-08) of FCAV/UNESP, Jaboticabal, state of São Paulo, Brazil.

\section{Acknowledgements}

Financial assistance was provided by FAPESP (Fundação de Amparo à Pesquisa do Estado de Sáo Paulo; no. 2009/07815-4). P.R.R. Moreira was supported by a grant from FAPESP (n. 2009/15736-7). 
D.A. Franciscato (no. 2008/03504-1) was also FAPESP grantee. S.R. Micelli was a CNPq grantee (Conselho Nacional do Desenvolvimento Científico e Tecnológico). The authors wish to acknowledge Mrs. F.A. Ardisson for her histotechnical assistance.

\section{References}

Barbiéri CL. Immunology of canine leishmaniasis. Parasite Immunol 2006; 28(7): 329-337. http://dx.doi.org/10.1111/j.1365-3024.2006.00840.x. PMid:16842269.

Barcinski MA, Moreira MEC, Balanco JMF, Wanderley JLM, Bonomo AC. The role of apoptotic mimicry in host-parasite interplay: is death the only alternative for altruistic behavior? Kinetoplastid Biol Dis 2003; 2(1): 6. http://dx.doi.org/10.1186/1475-9292-2-6. PMid:12857353.

Brasil. Ministério da Saúde. Secretaria de Vigilância em Saúde. Departamento de Vigilância Epidemiológica. Manual de vigilância e controle da Leishmaniose Visceral [online]. Brasília: MS; 2006 [cited 2016 Jun 20]. 122 p. Série A: normas e manuais técnicos. Available from: http://bvsms.saude.gov.br/ bvs/publicacoes/manual_vigilancia_controle_leishmaniose_visceral.pdf

Feitosa MM, Ikeda FA, Luvizotto MCR, Perri SHV. Aspectos clínicos de cães com Leishmaniose Visceral no município de Araçatuba, São Paulo (Brasil). Rev Clin Vet 2000; 28: 36-44.

Giunchetti RC, Mayrink W, Carneiro CM, Côrrea-Oliveira R, MartinsFilho OA, Marques MJ, et al. Histopathological and immunohistochemical investigations of the hepatic compartment associated with parasitism and serum biochemical changes in canine visceral leishmaniasis. Res Vet Sci 2008; 84(2): 269-277. http://dx.doi.org/10.1016/j.rvsc.2007.04.020. PMid:17604064.

González JL, Rollán E, Novoa C, Castaño M. Structural and ultrastructural hepatic changes in experimental canine leishmaniasis. Histol Histopathol 1998; 3(4): 323-329. PMid:2980240.

Lima VMF, Fattori KR, Souza F, Eugênio FR, Santos PSP, Rozza DB, et al. Apoptosis in T lymphocytes from spleen tissue and peripheral blood of L. (L.) chagasi naturally infected dogs. Vet Parasitol 2012; $184(2-4)$ : $147-$ 153. http://dx.doi.org/10.1016/j.vetpar.2011.08.024. PMid:21899954.

Lima WG, Oliveira PS, Caliari MV, Gonçalves R, Michalick MSM, Melo MN, et al. Histopathological and immunohistochemical study of type 3 complement receptors (CD11b/CD18) in livers and spleens of asymptomatic and symptomatic dogs naturally infected with Leishmania (Leishmania) chagasi. Vet Immunol Immunopathol 2007; 117(1-2): 129136. http://dx.doi.org/10.1016/j.vetimm.2007.02.012. PMid:17383741.

Lüder CGK, Gross UWE, Lopes MF. Intracellular protozoan parasites and apoptosis: diverse strategies to modulate parasite-host interactions. Trends Parasitol 2001; 17(10): 480-486. http://dx.doi.org/10.1016/ S1471-4922(01)02016-5. PMid:11587962.

Melo SMB, Larangeira DF, Trigo J, Aguiar PHP, Santos WLC, Carvalho LP. Comparison between splenic and lymph node aspirations as sampling methods for the parasitological detection of Leishmania chagasi infection in dogs. Mem Inst Oswaldo Cruz 2004; 99(2): 195-197. http://dx.doi. org/10.1590/S0074-02762004000200014. PMid:15250475.

Moreira PRR, Bandarra MB, Magalhães GM, Munari DP, Machado GF, Prandini MM, et al. Influence of apoptosis on the cutaneous and peripheral lymph node inflammatory response in dogs with visceral leishmaniasis. Vet Parasitol 2013; 192(1-3): 149-157. http://dx.doi. org/10.1016/j.vetpar.2012.09.029. PMid:23084537.

Moreira PRR, Vieira LM, Andrade MMC, Bandarra MB, Machado GF, Munari DP, et al. Immune response pattern of the popliteal lymph nodes of dogs with visceral leishmaniasis. Parasitol Res 2010; 107(3): 605-613. http://dx.doi.org/10.1007/s00436-010-1902-2. PMid:20499098.

Murali AK, Mehrotra S. Apoptosis: an ubiquitous T cell immunomodulator. J Clin Cell Immunol 2011; S3(Suppl 3): 2. PMid:23504027.

Oliveira TMFS, Furuta PI, Carvalho D, Machado RZ. A study of crossreactivity in serum samples from dogs positive for Leishmania sp., Babesia canis and Ehrlichia canis in enzyme-linked immunosorbent assay and indirect fluorescent antibody test. Rev Bras Parasitol Vet 2008; 17(1): 7-11. PMid:18554433.

Reis AB, Martins-Filho OA, Carvalho AT, Giunchetti RC, Carneiro CM, Mayrink W, et al. Systemic and compartmentalized immune response in canine visceral leishmaniasis. Vet Immunol Immunopathol 2009; 128(1-3): 87-95. http://dx.doi.org/10.1016/j.vetimm.2008.10.307. PMid:19054576.

Rey L. Principais grupos de protozoários e metazoários, parasitos do homem e seus vetores. In: Rey L. Parasitologia. 3rd ed. Rio de Janeiro: Guanabara Koogan; 2001. p. 123-134.

Sanchez MA, Diaz NL, Zerpa O, Negron E, Convit J, Tapia FL. Organspecific immunity in canine visceral leishmaniasis: analysis of symptomatic and asymptomatic dogs naturally infected with Leishmania chagasi. Am J Trop Med Hyg 2004; 70(6): 618-624. PMid:15211002.

Santana CC, Vassallo J, De Freitas LAR, Oliveira GGS, Pontes-DeCarvalho LC, Dos-Santos WLC. Inflammation and structural changes of splenic lymphoid tissue in visceral leishmaniasis: a study on naturally infected dogs. Parasite Immunol 2008; 30(10): 515-524. http://dx.doi. org/10.1111/j.1365-3024.2008.01051.x. PMid:18665902.

Solano-Gallego L, Miró G, Koutinas A, Cardoso L, Pennisi M, Ferrer L, et al. LeishVet guidelines for the practical management of canine leishmaniosis. Parasit Vectors 2011; 4(1): 86. http://dx.doi.org/10.1186/1756-3305-486. PMid:21599936.

Tafuri WL, Santos RL, Arantes RME, Gonçalves R, Melo MN, Michalick MSM, et al. An alternative immunohistochemical method for detecting Leishmania amastigotes in paraffin-embedded canine tissues. J Immunol Methods 2004; 292(1-2): 17-23. http://dx.doi.org/10.1016/j. jim.2004.05.009. PMid:15350508.

Tafuri WL, Tafuri WL, Barbosa JAA, Michalick MSM, Genaro O, França-Silva JC, et al. Histopathology and immunocytochemical study of type 3 and type 4 complement receptors in the liver and spleen of dogs naturally and experimentally infected with Leishmania (Leishmania) chagasi. Rev Inst Med Trop Sao Paulo 1996; 38(2): 81-89. http://dx.doi. org/10.1590/S0036-46651996000200001. PMid:9071026.

Tasca KI, Buzetti WAS, Tenório MS, Paulan SC, Lima FL, Queiroz NMGP, et al. Exames parasitológicos, imunoistoquímicos e histopatológicos para detecção de Leishmania chagasi em tecidos esplênicos de cães com leishmaniose visceral. Rev Bras Parasitol Vet 2009; 18(1): 27-33. http:// dx.doi.org/10.4322/rbpv.01801005. PMid:19500457.

Verçosa BLA, Melo MN, Puerto HLD, Mendonça IL, Vasconcelos AC. Apoptosis, inflammatory response and parasite load in skin of Leishmania (Leishmania) chagasi naturally infected dogs: a histomorphometric analysis. Vet Parasitol 2012; 189(2-4): 162-170. http://dx.doi.org/10.1016/j. vetpar.2012.04.035. PMid:22694833. 